Research Article

\title{
XPS Studies of LSCF Interfaces after Cell Testing
}

\author{
Gianfranco DiGiuseppe $\mathbb{D}$, Venkatesh Boddapati, and Hiten Mothikhana \\ Department of Mechanical Engineering, Kettering University, 1700 University Avenue, Flint, MI 48504-4898, USA \\ Correspondence should be addressed to Gianfranco DiGiuseppe; gdigiuse@kettering.edu
}

Received 1 November 2017; Revised 7 December 2017; Accepted 28 December 2017; Published 11 February 2018

Academic Editor: Claude Estournès

Copyright (C) 2018 Gianfranco DiGiuseppe et al. This is an open access article distributed under the Creative Commons Attribution License, which permits unrestricted use, distribution, and reproduction in any medium, provided the original work is properly cited.

\begin{abstract}
The motivation of this investigation is to explore the possibility of using the depth profile capability of XPS to study interfaces after SOFC button cell testing. The literature uses XPS to study various cathode materials but has devoted little to the understanding of various cathode interfaces especially after testing. In this work, an SOFC button cell is first tested, and then, the LSCF cathode, barrier layer, and electrolyte are sputtered away to study the behavior of different interfaces. This work has shown that some elements have moved into other layers of the SOFC cell. It is argued that the migration of the elements is partly due to a redeposition mechanism after atoms are sputtered away, while the rest is due to interdiffusion between the SDC and YSZ layers. However, additional work is needed to better understand the mechanism by which atoms move around at different interfaces. The cell electrochemical performance is also discussed in some details but is not the focus.
\end{abstract}

\section{Introduction}

Solid oxide fuel cells (SOFCs) are potential candidates for a variety of power generation applications. They are not limited by the Carnot cycle and therefore are highly efficient as well as modular and possess cogeneration capabilities. These attributes can extend the total efficiency of SOFC systems to over $80 \%$. Because of these high efficiencies, SOFC systems are expected to penetrate the portable, automotive, residential, commercial building markets as well as large power plants $[1,2]$. Other benefits of SOFCs are that they can operate over a wide range of temperatures $\left(600-1000^{\circ} \mathrm{C}\right)$ depending upon the material used and are fuel flexible [3]. Of special interest is the reduction of the operating temperature to the low end of the abovementioned range because it would allow the stack to better tolerate thermal cycling for improved reliability. In recent years, SOFC development has been accelerating, with several prototypes being built and tested at different sites [4]. Despite the progress made, the cathode remains a strong subject of research because of long-term degradation due to strontium segregation and/or chromium poisoning from balance of plant components $[5,6]$.

Several researchers have used XPS techniques to study the cathode material for SOFCs and reported various trends and chemical properties. For instance, van der Heide reports a study of lanthanum-strontium-based perovskite where different binding energies are observed for surface and bulk elements. Several samples of $\mathrm{ABO}_{3}$ were tested where $\mathrm{La}$ and $\mathrm{Sr}$ occupy the A site. The B site consisted of mixtures of $\mathrm{Fe} / \mathrm{Ga}, \mathrm{Fe} / \mathrm{Co}, \mathrm{Fe} / \mathrm{Cr}, \mathrm{Co} / \mathrm{Ga}$, or Co only [7]. Wu et al. report a study of lanthanum strontium manganite and show that Sr-rich phases are present [8]. Crumlin et al. report a study of $\mathrm{La}_{0.8} \mathrm{Sr}_{0.2} \mathrm{CoO}_{3-\delta}$ film where surface chemistry changes are investigated [9]. Similar studies related to SOFC cathodes can be found in the literature investigating different aspects of material processing and chemical properties [10-14].

No studies, though, have been reported where the cathode material is removed, and various interfaces are studied after cell testing. Also, XPS techniques or depth profiling can provide the chemical state of an element in addition to compositional data. For instance, SEM-EDS elemental analysis can provide compositional data but cannot determine the chemical state of an element. Hence, it is the purpose of this effort to better understand SOFC interfaces after testing of a button cell. After the electrochemical characterization has been completed, the button cell is sectioned for XPS depth analysis normal to the cathode. As the LSCF cathode, barrier layer, and electrolyte 


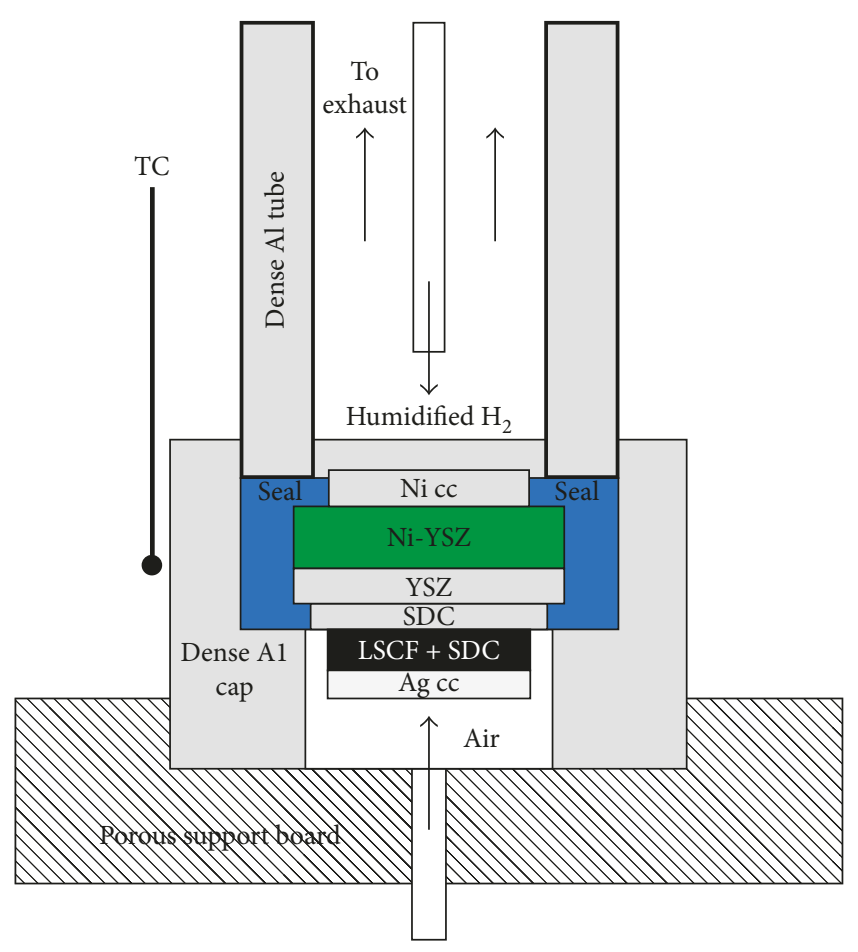

FIGURE 1: Schematics of the button cell testing setup used for this work.

are sputtered away, the relevant element concentrations are measured at different depths. The behavior of the observed element concentrations is discussed in detail especially at different interfaces. In addition, the Sr3d peaks are compared at different locations within the button cell to determine if changes in the chemical state can be observed.

\section{Experimental}

An anode-supported SOFC button cell was obtained from a commercial supplier for this project. The anode comprised state-of-the-art nickel and yttria-stabilized zirconia (NiYSZ) cermet, while the electrolyte consists of state-of-theart YSZ. The cathode material is made of a mixture of lanthanum strontium cobalt ferrite (LSCF) and samariumdoped ceria (SDC). A thin ceria buffer layer (also SDC) between the electrolyte and cathode is used to prevent undesired reactions. The details of the cell testing setup are shown in Figure 1. The temperature is monitored by placing a thermocouple very close to the cell as shown in the figure. For our purpose, the button cell was tested at 700 and $750^{\circ} \mathrm{C}$. In the anode side, humidified hydrogen was used at room temperature with a flow rate of 1 SLPM. In the cathode side, air was used as an oxidant with a flow rate of 1 SLPM. Nickel and silver current collectors are used in a 4-probe voltage/current measurement. A commercial seal is used to prevent any fuel and air mixing. Voltage and current density curves as well as impedance measurements were made using a PARSTAT 2273 apparatus coupled with a power booster obtained from AMETEK Princeton Applied Research. For voltage-current density curves, the cell voltage is swept at

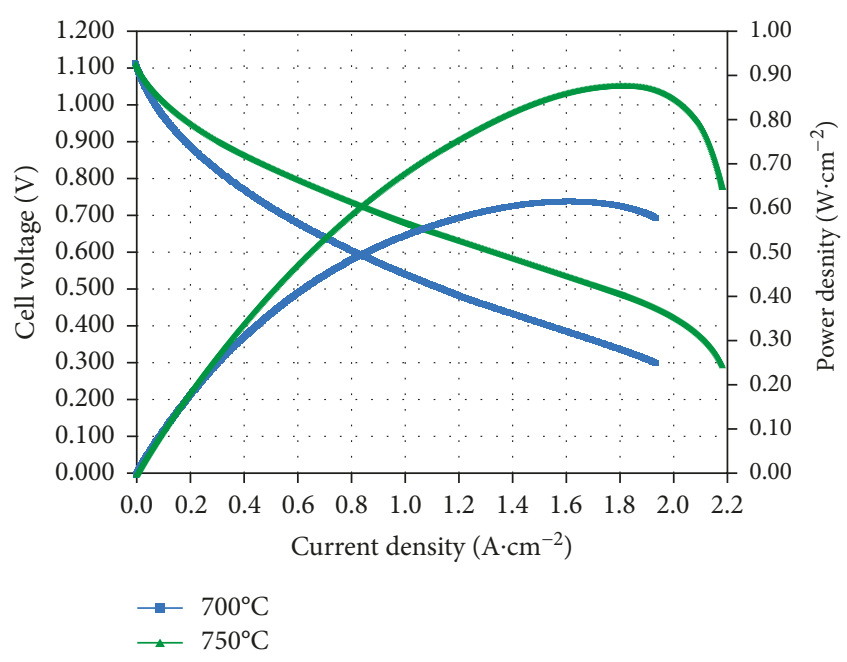

FIgURE 2: Voltage and power density versus current density for the tested cell.

$3 \mathrm{mV} / \mathrm{s}$. Electrochemical impedance spectroscopy data were obtained at open-circuit voltage. The frequency range was between $0.01 \mathrm{~Hz}$ and $1 \mathrm{MHz}$ with an AC amplitude of $10 \mathrm{mV}$ and 12 datum points per frequency decade. The XPS data were collected using the PHI X-tool automated XPS microprobe from Physical Electronics, a division of ULVACPHI, Inc. The collected XPS data were then analyzed using the MultiPak software version 9.5.0.8 also provided by ULVAC-PHI. For reference and comparison purposes, LSCF powder from the fuel cell material (FCM) with nominal composition of $\left(\mathrm{La}_{0.60} \mathrm{Sr}_{0.40}\right)_{0.95} \mathrm{Co}_{0.20} \mathrm{Fe}_{0.80} \mathrm{O}_{3-\delta}$ was purchased, and XPS data were also collected. This composition should be in line with cathode composition used in the tested cell. The XPS sputtering rate was set at $28 \mathrm{~nm} / \mathrm{min}$. The cathode of the tested cell was sputtered normal to the cathode and was stopped after about $50 \mu \mathrm{m}$ of the material was removed. Since the focus of this work is on the cathode side, the $\mathrm{Ni}$ concentration on the anode was not measured to reduce machine usage time.

\section{Discussion and Results}

Figure 2 reports the voltage-current densities obtained at different temperatures. The open-circuit voltage is measured to be 1.112 and $1.102 \mathrm{~V}$ at 700 and $750^{\circ} \mathrm{C}$, respectively. Comparing these values to the theoretical ones, calculated using the Nernst equation from [1] to be 1.119 and $1.110 \mathrm{~V}$ at 700 and $750^{\circ} \mathrm{C}$, respectively, indicates a well-sealed cell without any mixing of fuel and air. The cell performance reported here is reasonably in line with other reported data using LSCF cathodes [15]. At $750^{\circ} \mathrm{C}$, the cell shows low activation overpotential, but diffusion losses are significant at high current densities as shown by the curve bending. At $700^{\circ} \mathrm{C}$, the activation overpotential has increased as expected, but diffusion losses are less dominant. The impedance data are reported in Figure 3. From the figure, the ohmic resistance (high-frequency intercept) and total polarization (low-frequency intercept) can be estimated for 


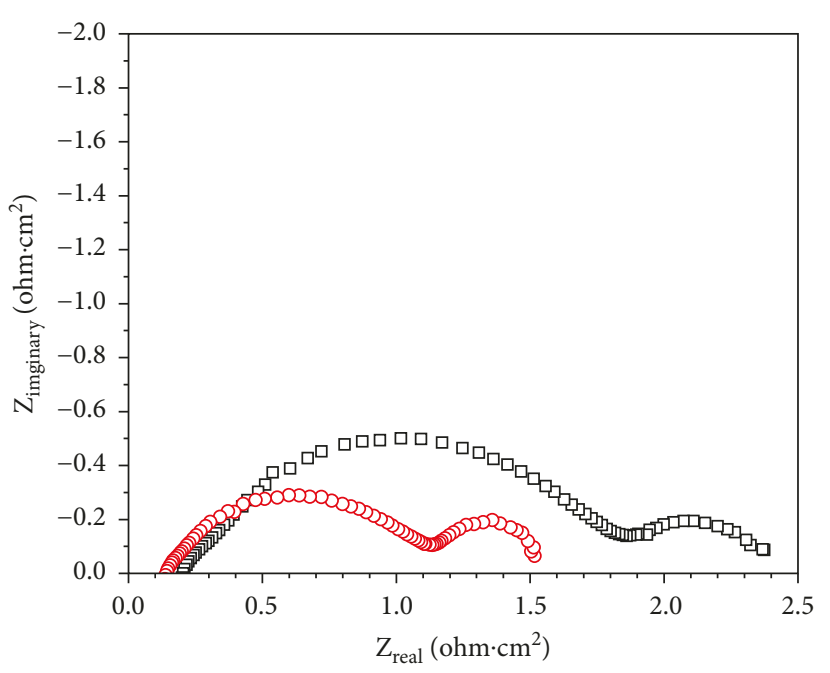

$700^{\circ} \mathrm{C}$

○ $750^{\circ} \mathrm{C}$

FIGURE 3: Nyquist representation of the impedance data for the tested cell.

each temperature. The electrode polarization can be estimated by the distance from the high- to low-resistance intercept. In addition, the semicircles at the low frequency range are generally related to diffusion processes, while the others are related to activation processes [16]. From the data, it can be observed that the ohmic resistance is lower at $750^{\circ} \mathrm{C}$. This is due to higher ionic conductivity of the YSZ electrolyte at higher temperatures and therefore contributes less to the ohmic resistance. At $700^{\circ} \mathrm{C}$, the highfrequency semicircle is much larger due to increased activation losses which are again due to temperature effects. Diffusion losses are present at both temperatures as evidenced by the low-frequency semicircle; however, the semicircles are almost the same for both temperatures, given the non-Arrhenius-like dependency for gas diffusion processes. Figure 4 shows an SEM picture, postmortem, of the tested cell. Some damage has occurred during the removal of the cell from the test rig and subsequent cell mounting and polishing. This is because some cathode is missing, and some separation has occurred between the electrolyte and ceria layer. At any rate, the electrolyte is very dense, while the ceria layer shows some minor porosity. The LSCF cathode has higher porosity as is crucial to lower oxygen diffusion losses.

Table 1 reports the XPS data collected for two samples of untested LSCF powders. Both samples were first sputtered for a few minutes to remove surface contamination. The obtained atomic percent is compared with the expected nominal composition, and a relative error is determined. Except for oxygen, the relative errors are very large. The large errors are mostly due to the nature of the XPS technique which is surface limited to a few atomic layers [7]. Other techniques such as EDX are more bulk analysis oriented and have shown smaller errors for the same type of the sample (data not reported). The cobalt element error is affected the most out of the other elements. Variations with the XPS collection settings, such as the time and number of passes,

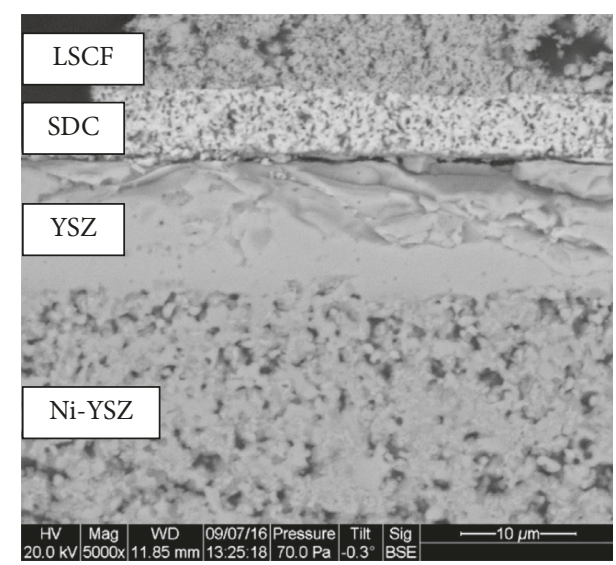

Figure 4: Cross section SEM picture of the SOFC cell.

TABLE 1: Experimental atomic concentrations for the as-received LSCF powder from FCM obtained from XPS measurements on samples with nominal composition of $\left(\mathrm{La}_{0.60} \mathrm{Sr}_{0.40}\right)_{0.95} \mathrm{Co}_{0.20} \mathrm{Fe}_{0.80} \mathrm{O}_{3-\delta}$.

\begin{tabular}{lccccc}
\hline & \multicolumn{5}{c}{ Atomic percent } \\
& $\mathrm{La}$ & $\mathrm{Sr}$ & $\mathrm{Co}$ & $\mathrm{Fe}$ & $\mathrm{O}$ \\
\hline Sample 1 & $12.3 \%$ & $6.9 \%$ & $9.4 \%$ & $11.9 \%$ & $59.6 \%$ \\
Sample 2 & $12.1 \%$ & $6.7 \%$ & $8.7 \%$ & $11.7 \%$ & $60.8 \%$ \\
Average & $12.2 \%$ & $6.8 \%$ & $9.1 \%$ & $11.8 \%$ & $60.2 \%$ \\
Expected & $11.4 \%$ & $7.6 \%$ & $4.0 \%$ & $16.0 \%$ & $60.0 \%$ \\
Error & $7.0 \%$ & $10.5 \%$ & $126.3 \%$ & $26.3 \%$ & $0.3 \%$ \\
& & & Formula & & \\
Average & 0.61 & 0.34 & 0.45 & 0.59 & 3.01 \\
Expected & 0.57 & 0.38 & 0.20 & 0.80 & 3.00 \\
\hline
\end{tabular}

have not shown a substantial improvement or change in the estimated relative error, hence confirming the very sensitive surface nature of XPS. These data will be used to compare the data obtained from the tested cathode if significant change is observed.

Figure 5 reports the depth profile data of the cathode as the material is removed normal to the surface of the cathode. All pertinent elements are identified by the XPS machine, and the various peaks of interest, from where the atomic concentrations are estimated, are shown in the graph legend. Again, the Ni concentration on the anode was not measured to reduce machine usage time. The large amount of data makes the graph hard to read, but the location where the electrolyte begins can be assumed to be at around $30.5 \mu \mathrm{m}$. The location is indicated by the black line, and it represents the sharp increase of the Zr3d peak and to a lesser extent the Y3d peak. The cathode elements are relatively constant until they start dropping off around $25 \mu \mathrm{m}$ at which point the Sm and Ce elements start increasing. From the SEM picture, the ceria layer can be approximated to be around $5 \mu \mathrm{m}$; however, the XPS data indicate that the SDC elements are present within a layer of about $10 \mu \mathrm{m}$. The oxygen concentration increases as the ceria layer starts and indicates the higher amount of oxygen present in the lattice when compared to the cathode perovskite. Noticeable is the presence of Sm and Ce within the cathode as expected, but they are also present 


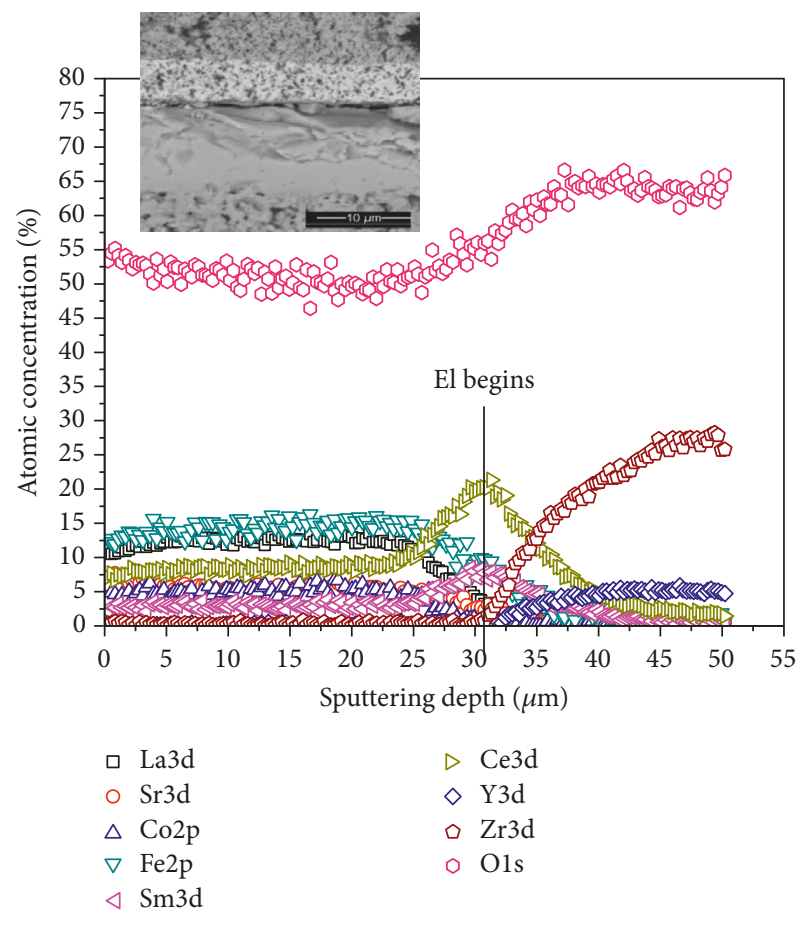

FIGURE 5: Atomic concentrations obtained from XPS depth profile measurements for the relevant elements in the tested SOFC.

in the electrolyte which needs further exploration. Also noticeable is the lack of sharp interfaces among any of the layers; in other words, there is a smooth transition either increasing or decreasing as each layer is reached.

In Figure 6, the cathode elements have been removed from the graph to better illustrate the behavior of the $\mathrm{Sm}$ and Ce concentrations. Clearly, both elements are present in the cathode which makes it a composite cathode. Their concentrations are relatively constant throughout the cathode and increase rapidly when the barrier layer is reached. The addition of a secondary phase to perovskite cathodes is common in the literature even for LSCF [17]. Composite cathodes are used in SOFC because they provide mixed conductivity, therefore enhancing the oxygen reduction reactions [18]. The $\mathrm{Sm}$ and Ce presence in the electrolyte layer is more difficult to explain but indicates interdiffusion between the SDC and YSZ layers. In addition, the sharp maximum observed in both elements is puzzling as one would expect a plateau, or a short zone of constant concentrations should be present within the barrier layer.

Interdiffusion between the SDC and YSZ layers has been recently reported for cells fired at $1400^{\circ} \mathrm{C}$ and occurs at firing temperatures above $1200^{\circ} \mathrm{C}$ [19]. Similar behavior has been reported for a ceria barrier layer doped with gadolinium as well [20]. For SDC/YSZ bilayers, where the YSZ layer is deposited, using a pulsed laser deposition technique avoids the hightemperature firing step, and the interdiffusion between the two layers has not been observed [21]. Additional studies report that the dissolution of Sm into the YSZ phase can also result in decreased ionic conductivity in the electrolyte [22, 23].

The lack of a plateau in the ceria layer suggests that some other processes may be occurring at the same time. For

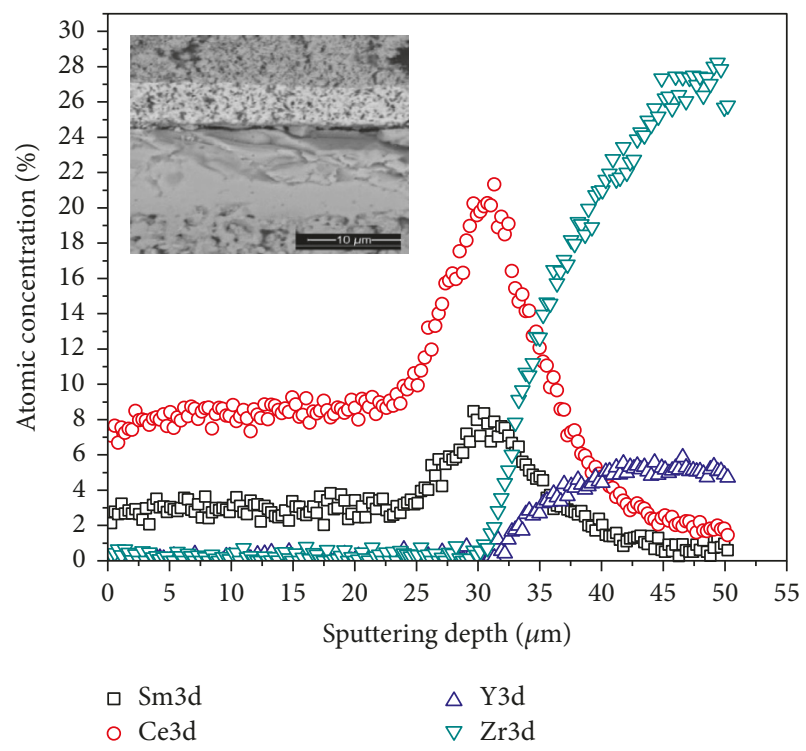

FIgURE 6: Atomic concentrations obtained from XPS depth profile measurements for $\mathrm{Sm}, \mathrm{Ce}, \mathrm{Y}$, and $\mathrm{Zr}$ elements.

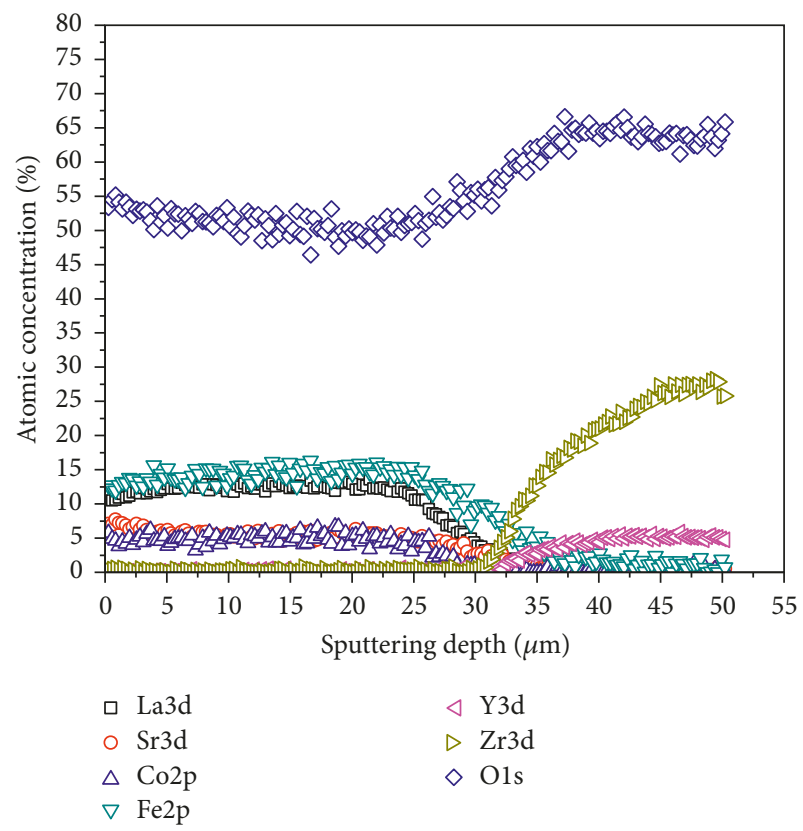

FIgURE 7: Atomic concentrations obtained from XPS depth profile measurements for LSCF, Y, and Zr elements.

instance, some redeposition of Sm and Ce may be occurring. In other words, as these elements are sputtered away, some of them redeposit and contribute to the measured concentration as the depth profile increases. Similar behavior is shown for $\mathrm{Zr}$ where a plateau is reached much later than for $Y$. However, this argument needs additional experimentation before it can be confirmed. Finally, it is worth noting that Ce lingers for a long time where it is still present for depths larger than $40 \mu \mathrm{m}$.

In Figure 7, the ceria layer elements have been removed to better visualize the cathode element behavior near the 


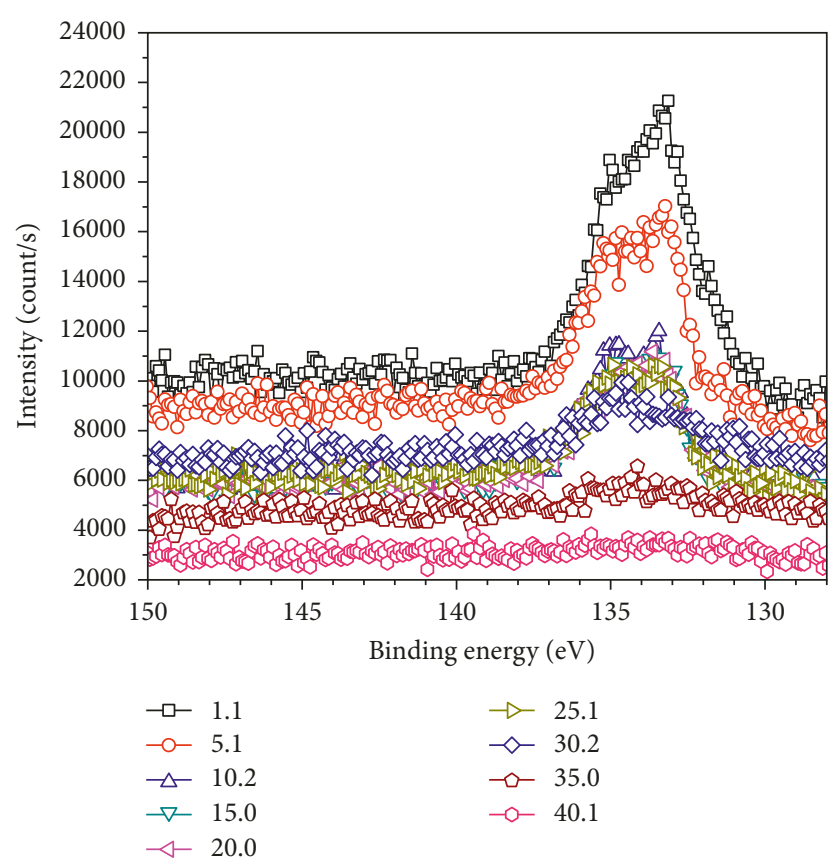

FIGURE 8: Sr3d peaks obtained from XPS depth profile measurements at different depths in micrometers.

electrolyte interface. The cathode elements are reasonably in line with the powder XPS data shown in Table 1 within the experimental error observed which can be large. Therefore, no significant change can be discerned from untested LSCF powders to tested LSCF cathodes. Their concentrations are relatively constant until they reach the ceria layer around $25 \mu \mathrm{m}$. The concentrations (from high to low) of $\mathrm{Fe}, \mathrm{La}$, and Sr have extended into the ceria barrier layer. Though some of these may have migrated beforehand into the layer, some redeposition may also be going on. Iron shows the largest concentration, which may indicate that it is already present in the ceria layer. Iron oxide has been used as a dopant for ceria barrier layers [24]. Except for the iron, no other cathode elements are observed in the electrolyte layer which may indicate some kind of a redeposition mechanism or interdiffusion.

Finally, the Sr3d peaks are plotted in Figure 8 at different depths. The peaks show the expected pattern with a doublet. The binding energies are around 133 and $135 \mathrm{eV}$ which are assigned to $\mathrm{Sr} 3 \mathrm{~d}_{5 / 2}$ and $\mathrm{Sr} 3 \mathrm{~d}_{3 / 2}$, respectively [8]. The Sr peaks do not seem to change or shift as the depth increases. This indicates that the $\mathrm{Sr}$ chemical state has not changed. In other words, there should not be any other compounds other than Sr present within the LSCF cathode.

\section{Conclusion and Future Work}

In this work, a commercial anode-supported SOFC has been electrochemically tested, and then, a detailed XPS depth analysis through the LSCF cathode has been performed. The electrochemical performance is in line with other published works when LSCF is used as the cathode. The cell voltagecurrent density data show a larger diffusion component at $750^{\circ} \mathrm{C}$ and a significant activation component at $700^{\circ} \mathrm{C}$. The XPS depth profile data show that some elements have moved around and penetrated into other cell layers. It is hypothesized that a redeposition mechanism after atoms are sputtered away is partly responsible for the observed behavior, while the rest is due to interdiffusion between the SDC and YSZ layers. Future work should concentrate closer to the interfaces or use a different technique to determine if the same behavior can be observed.

\section{Conflicts of Interest}

The authors declare that they have no conflicts of interest.

\section{Acknowledgments}

The work presented in this paper was partially supported by the Department of Energy (DOE) through the National Energy Technology Laboratory (NETL) under Award Number DE-FE0026168. Special thanks are due to Graham Garner for his help with the XPS machine.

\section{References}

[1] S. C. Singhal, "Solid oxide fuel cells for stationary, mobile and military applications," Solid State Ionics, vol. 152-153, pp. 405-410, 2002.

[2] P. Lamp, J. Tachtler, O. Finkenwirth, S. Mukerjee, and S. Shaffer, "Development of auxiliary power unit with solid oxide fuel cells for automotive application," Fuel Cells, vol. 3, no. 3, pp. 146-152, 2003.

[3] N. Mahato, A. Banerjee, A. Gupta, S. Omar, and K. Balani, "Progress in material selection for solid oxide fuel cell technology: a review," Progress in Materials Science, vol. 72, pp. 141-337, 2015.

[4] N. Q. Minh, "Solid oxide fuel cell technology-features and applications," Solid State Ionics, vol. 174, no. 1-4, pp. 271-277, 2004.

[5] F. Tietz, A. Mai, and D. Stöver, "From powder properties to fuel cell performance: a holistic approach for SOFC cathode development," Solid State Ionics, vol. 179, no. 27-32, pp. 1509-1515, 2008.

[6] Y. D. Zhen, A. I. Y. Tok, S. P. Jiang, and F. Y. C. Boey, "La(Ni, $\mathrm{Fe}) \mathrm{O}_{3}$ as a cathode material with high tolerance to chromium poisoning for solid oxide fuel cells," Journal of Power Sources, vol. 170, no. 1, pp. 61-66, 2007.

[7] P. A. W. van der Heide, "Systematic x-ray photoelectron spectroscopic study of $\mathrm{La}_{1} \mathrm{x} \mathrm{Sr}_{\mathrm{x}}$-based perovskite-type oxides," Surface and Interface Analysis, vol. 33, no. 5, pp. 414-425, 2002.

[8] Q. H. Wu, M. Liu, and W. Jaegermann, "X-ray photoelectron spectroscopy of $\mathrm{La}_{0.5} \mathrm{Sr}_{0.5} \mathrm{MnO}_{3}$," Materials Letters, vol. 59, no. 16, pp. 1980-1983, 2005.

[9] E. J. Crumlin, E. Mutoro, Z. Zhi Liu et al., "Surface strontium enrichment on highly active perovskites for oxygen electrocatalysis in solid oxide fuel cells," Energy \& Environmental Science, vol. 5, no. 3, pp. 6081-6088, 2012.

[10] J. Kuyyalil, D. Newby Jr., J. Laverock et al., "Vacancy assisted SrO formation on $\mathrm{La}_{0.8} \mathrm{Sr}_{0.2} \mathrm{Co}_{0.2} \mathrm{Fe}_{0.8} \mathrm{O}_{3-\delta}$ surfaces-a synchrotron photoemission study," Surface Science, vol. 642, pp. 33-38, 2015.

[11] Z. Cai, M. Kubicek, J. Fleig, and B. Yildiz, "Chemical heterogeneities on $\mathrm{La}_{0.6} \mathrm{Sr}_{0.4} \mathrm{CoO}_{3-\delta}$ thin films-correlations to 
cathode surface activity and stability," Chemistry of materials, vol. 24, no. 6, pp. 1116-1127, 2012.

[12] N. Caillol, M. Pijolat, and E. Siebert, "Investigation of chemisorbed oxygen, surface segregation and effect of posttreatments on $\mathrm{La}_{0.8} \mathrm{Sr}_{0.2} \mathrm{MnO}_{3}$ powder and screen-printed layers for solid oxide fuel cell cathodes," Applied Surface Science, vol. 253, no. 10, pp. 4641-4648, 2007.

[13] S. O. Lee, D. Lee, I. Jung et al., "Ceria interlayer-free $\mathrm{Ba} 0.5 \mathrm{Sr} 0.5 \mathrm{Co} 0.8 \mathrm{Fe} 0.2 \mathrm{O} 3-\delta$-Sc0.1Zr0.9O1.95 composite cathode on zirconia based electrolyte for intermediate temperature solid oxide fuel cells," International Journal of Hydrogen Energy, vol. 38, no. 22, pp. 9320-9329, 2013.

[14] P. Datta, P. Majewski, and F. Aldinger, "Study of gadoliniadoped ceria solid electrolyte surface by XPS," Materials Characterization, vol. 60, no. 2, pp. 138-143, 2009.

[15] E. P. Murray, M. J. Sever, and S. A. Barnett, "Electrochemical performance of $(\mathrm{La}, \mathrm{Sr})(\mathrm{Co}, \mathrm{Fe}) \mathrm{O}_{3}-(\mathrm{Ce}, \mathrm{Gd}) \mathrm{O}_{3}$ composite cathodes," Solid State Ionics, vol. 148, no. 1-2, pp. 27-34, 2002.

[16] R. O'Hayre, S. W. Cha, W. Colella, and F. B. Prinz, Fuel Cell Fundamentals, John Wiley \& Sons, New York, NY, USA, 2005.

[17] Y. Leng, S. H. Chan, and Q. Liu, "Development of LSCF-GDC composite cathodes for low-temperature solid oxide fuel cells with thin film GDC electrolyte," International Journal of Hydrogen Energy, vol. 33, no. 14, pp. 3808-3817, 2008.

[18] J. W. Kim, A. V. Virkar, K. Z. Fung, K. Mehta, and S. C. Singhal, "Polarization effects in intermediate temperature, anode-supported solid oxide fuel cells," Journal of the Electrochemical Society, vol. 146, no. 1, pp. 69-78, 1999.

[19] Z. Wang, X. Huang, Z. Lv et al., "Preparation and performance of solid oxide fuel cells with YSZ/SDC bilayer electrolyte," Ceramics International, vol. 41, no. 3, pp. 4410-4415, 2015.

[20] G. Constantin, C. Rossignol, J.-P. Barnes, and E. Djurado, "Interface stability of thin, dense CGO film coating on YSZ for solid oxide fuel cells," Solid State Ionics, vol. 235, pp. 36-41, 2013.

[21] J. Qian, Z. Tao, J. Xiao, G. Jiang, and W. Liu, "Performance improvement of ceria-based solid oxide fuel cells with yttriastabilized zirconia as an electronic blocking layer by pulsed laser deposition," International Journal of Hydrogen Energy, vol. 38, no. 5, pp. 2407-2412, 2013.

[22] T. Matsui, M. Komoto, H. Muroyama, K. Kishida, H. Inui, and K. Eguchi, "Degradation factors in $(\mathrm{La}, \mathrm{Sr})(\mathrm{Co}, \mathrm{Fe}) \mathrm{O}_{3-\delta}$ cathode $/ \mathrm{Sm}_{2} \mathrm{O}_{3}-\mathrm{CeO}_{2}$ interlayer $/ \mathrm{Y}_{2} \mathrm{O}_{3}-\mathrm{ZrO}_{2}$ electrolyte system during operation of solid oxide fuel cells," Journal of Power Sources, vol. 312, pp. 80-85, 2016.

[23] T. Matsui, S. Li, H. Muroyama, K. Kishida, H. Inui, and K. Eguchi, "Electrochemical property of solid solutions formed in $(\mathrm{La}, \mathrm{Sr})(\mathrm{Co}, \mathrm{Fe}) \mathrm{O}_{3-\delta}$ cathode/doped-CeO $\mathrm{C}_{2}$ interlayer $/ \mathrm{Y}_{2} \mathrm{O}_{3}-\mathrm{ZrO}_{2}$ electrolyte system during operation of solid oxide fuel cells," Solid State Ionics, vol. 300, pp. 135-139, 2017.

[24] T. S. Zhang, J. Ma, L. B. Kong, S. H. Chan, P. Hing, and J. A. Kilner, "Iron oxide as an effective sintering aid and a grain boundary scavenger for ceria-based electrolytes," Solid State Ionics, vol. 167, no. 1-2, pp. 203-207, 2004. 


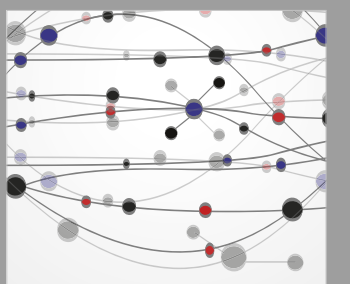

The Scientific World Journal
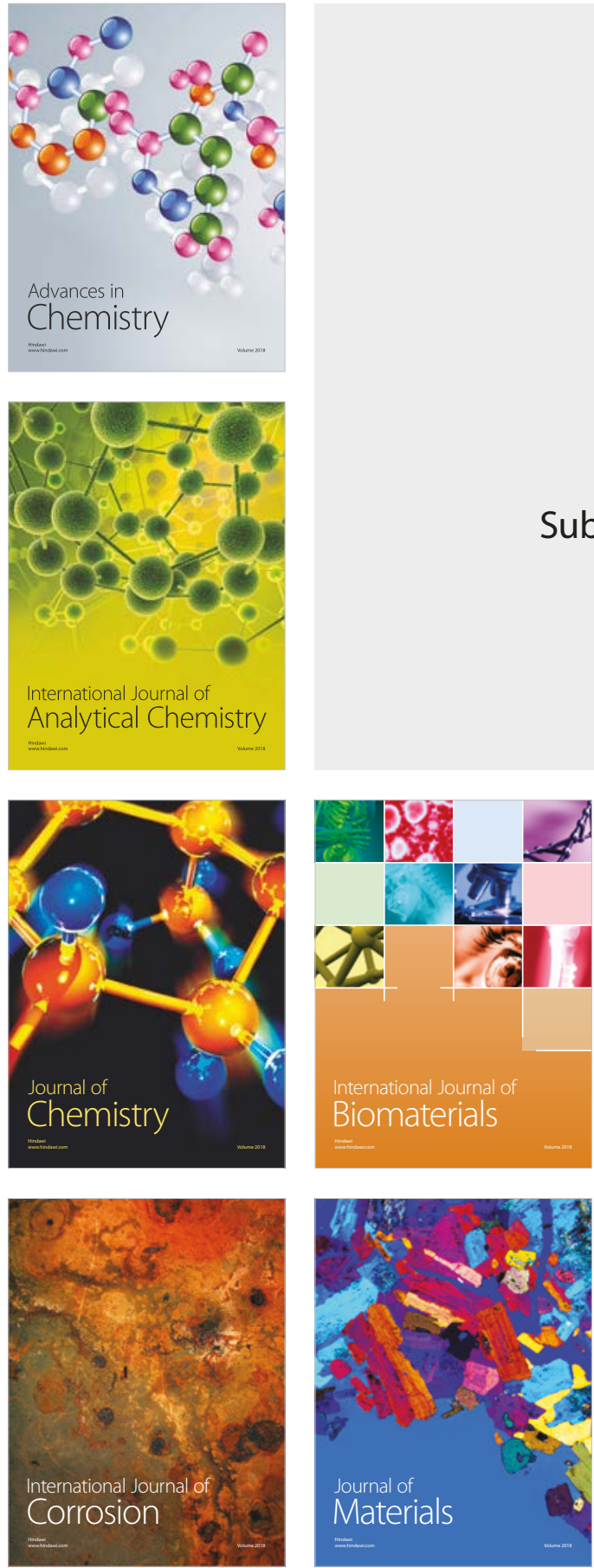

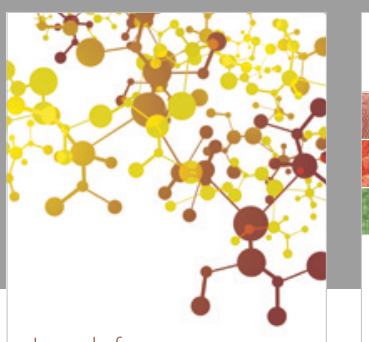

Journal of

Applied Chemistry
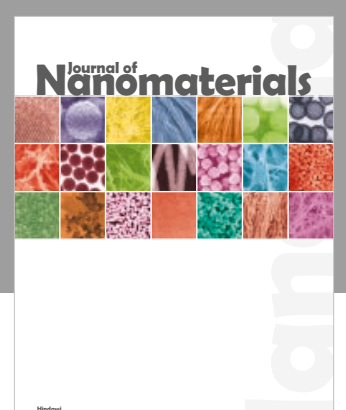

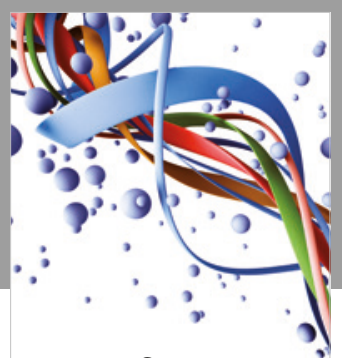

Scientifica

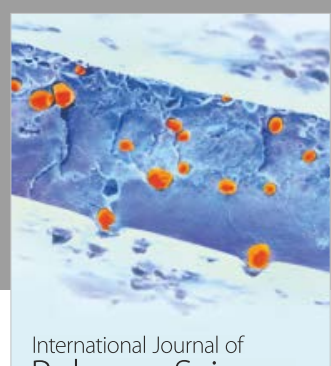

Polymer Science

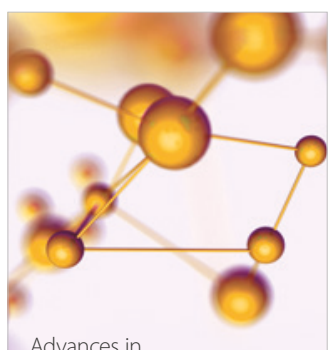

Physical Chemistry
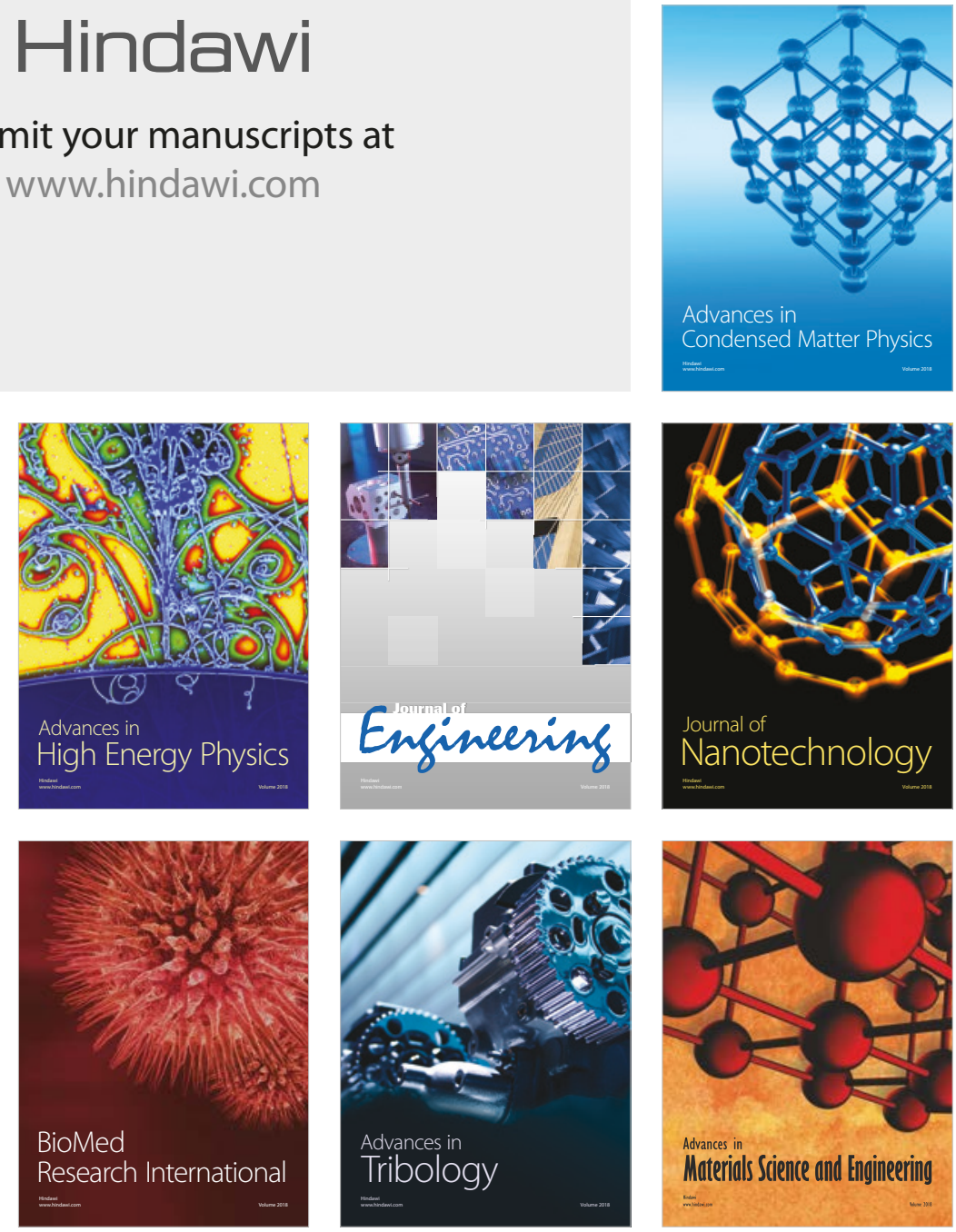